NOTE

\title{
Invasive walleye dermal sarcoma in laboratory-maintained walleyes Stizostedion vitreum
}

\author{
Kathy Earnest-Koons, Gregory A. Wooster, Paul R. Bowser*
}

Aquatic Animal Health Program, Department of Microbiology and Immunology, College of Veterinary Medicine, Cornell University, lthaca, New York 14853-6401, USA

\begin{abstract}
Walleye dermal sarcoma (WDS) was first described as a multifocal cutaneous neoplasm of walleyes Stizostedion vitreum in Oneida Lake, New York, USA. The neoplasm was subsequently shown to be caused by a type C retrovirus. We have successfully transmitted the neoplasm in laboratory-maintained young-of-the-year (YOY) walleyes in a number of pathogenesis studies over the past 6 yr. Neoplasms in these laboratory trials were typical of those superficial neoplasms observed in adult feral walleyes. A transmission study was begun summer 1994 using 9 wk old walleyes. Starting at $56 \mathrm{~d}$ and continuing throughout the experiment, injected fish developed grossly visible, multiple small white skin masses that varied from 0.5 to $10 \mathrm{~mm}$ in diameter. These masses appeared on the skin of the head, back, flank, fins and lips. Histopathological examination revealed that some of these neoplasms, especially those collected at $84 \mathrm{~d}$ and beyond, did not remain cutaneous, but. were locally invasive and replaced normal tissue, primarily muscle. One neoplasm on the head of a young walleye had deformed the brain and had invaded the skull. Due to the unusual invasive nature of the microscopic lesions of the neoplasm, these findings are reported.
\end{abstract}

KEY WORDS: Walleye Stizostedion vitreum - Neoplasia Retrovirus Transmission - Virus associated tumors - Dermal sarcoma

Dermal sarcoma is a lesion found on walleyes Stizostedion vitreum that was first described by Walker $(1947,1957,1958)$ in fish taken from Oneida Lake, New York, USA. He later hypothesized a viral etiology for the lesions (Walker 1961, 1969). The neoplasms have previously been described as highly cellular or densely fibrous and non-metastatic (Yamamoto et al. 1985, Martineau et al, 1990b). Dermal sarcoma has been transmitted experimentally by the intramuscular injection of cell-free filtrates of tumor homogenates into young-of-the-year (YOY) walleyes (Martineau et al.

\footnotetext{
·Addressee for correspondence. E-mail: prb4@cornell.edu
}

1990a). Transmission experiments conducted at 10, 15 , and $20^{\circ} \mathrm{C}$ demonstrated that the development of neoplasms was greatest at $15^{\circ} \mathrm{C}$, intermediate at $20^{\circ} \mathrm{C}$ and least at $10^{\circ} \mathrm{C}$ (Bowser et al. 1990). The putative virus has been cloned from neoplastic tissue and characterized as a member of the family Retroviridae (Martineau et al. 1991a, b, 1992). During a recent transmission experiment, invasive walleye dermal sarcoma lesions were observed in our laboratory for the first time. In this report, we document the pathology of these unique walleye dermal sarcomas.

Methods. The fish on which the invasive walleye dermal sarcomas were observed were part of a walleye dermal sarcoma pathogenesis study in which experimentally infected fish were collected for examination at designated time intervals during a $20 \mathrm{wk}$ trial. The results of the pathogenesis study will be reported elsewhere. The laboratory transmission model for walleye dermal sarcoma (Bowser et al. 1990, Martineau et al. 1990a, Bowser \& Wooster 1994) is described briefly below.

YOY walleyes were obtained from the New York State Department of Environmental Conservation (NYSDEC). These juvenile fish were part of the 1994 production at the NYSDEC Oneida Fish Hatchery, Constantia, New York, that utilizes feral Oneida Lake walleyes as broodfish. Swim-up fry from the Oneida Hatchery were transported to the NYSDEC South Otselic (New York) Fish Hatchery, where they were reared in earthen ponds. We obtained the fish at $9 \mathrm{wk}$ of age (46 mm mean total length). The fish were fed swim-up fry of fathead minnow Pimephales promelas ad libitum during the study.

The test inoculum consisted of a cell-free filtrate of walleye dermal sarcoma (WDS) collected in the spring while a cell-free filtrate of normal walleye skin served as the control (C) inoculum (Bowser \& Wooster 1994). 
Transmission attempts were performed by intramuscular injection of $0.05 \mathrm{ml}$ of inoculum into the right epaxial musculature near the base of the dorsal fin of the YOY fish. These fish were held in 37 l aquaria provided with running water at $15^{\circ} \mathrm{C}$ and aeration. Fifteen fish to be inoculated with WDS or $C$ inoculum were placed in each of 10 aquaria and allowed to acclimate for $1 \mathrm{wk}$. The test treatment (WDS) was randomly assigned to the fish in each of 8 aquaria, giving a total of 120 fish for the WDS treatment. Two aquaria containing 15 fish each were inoculated with the control inoculum. Fish were maintained in the aquaria for $20 \mathrm{wk}$ and ohserved daily for death or adverse signs. At designated sampling times, fish were euthanized with an overdose of tricaine methane sulfonate (MS-222) and examined grossly for neoplasms. Fish were then fixed in $10 \%$ neutral buffered formalin and 4 crosssections per fish were embedded in paraffin, sectioned and stained with hematoxylin and eosin prior to histological examination.

Results. On gross examination, there were multiple pale-white skin masses on approximately $90 \%$ of the WDS treated fish beginning at $56 \mathrm{~d}$ post injection. Most affected fish had 4 or 5 masses in various locations including the head, back, flank, and lips. The neoplasms varied from 0.5 to $10 \mathrm{~mm}$ in diameter. Most were solitary nodules, but occasionally several would coalesce (Fig. 1). No neoplasms were observed grossly or microscopically in fish receiving the control inoculum.

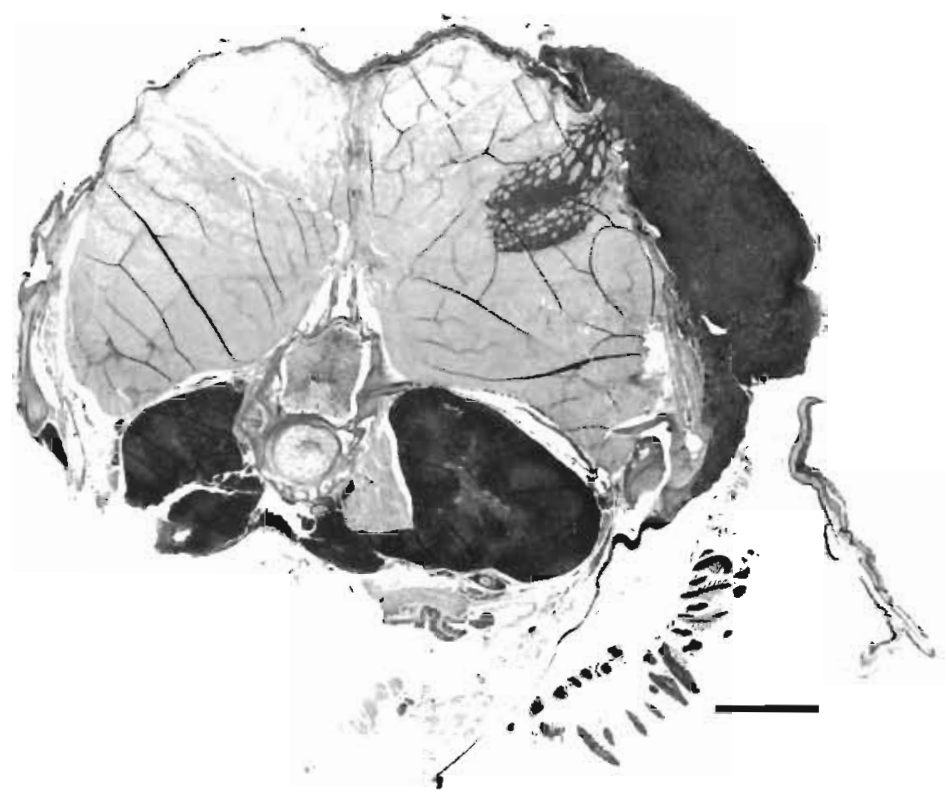

Fig. 2. Transverse section of young walleye at the level of the posterior margin of the operculum, showing dermal sarcoma that has invaded subdermal musculature. H\&E. Scale bar $=1.0 \mathrm{~mm}$

The histopathologic examination was very revealing. Previously the neoplasms induced from transmission studies were superficial neoplasms, like those observed in feral walleyes (Bowser et al. 1988, 1990, Martineau et al. 1990a, Bowser \& Wooster 1991). At Day 84 and beyond in this trial, many neoplasms were found to be locally invasive, especially in the subdermal musculature (Figs. 2 \& 3). Large foci of muscle have been replaced by neoplastic cells (Fig. 4). Additionally

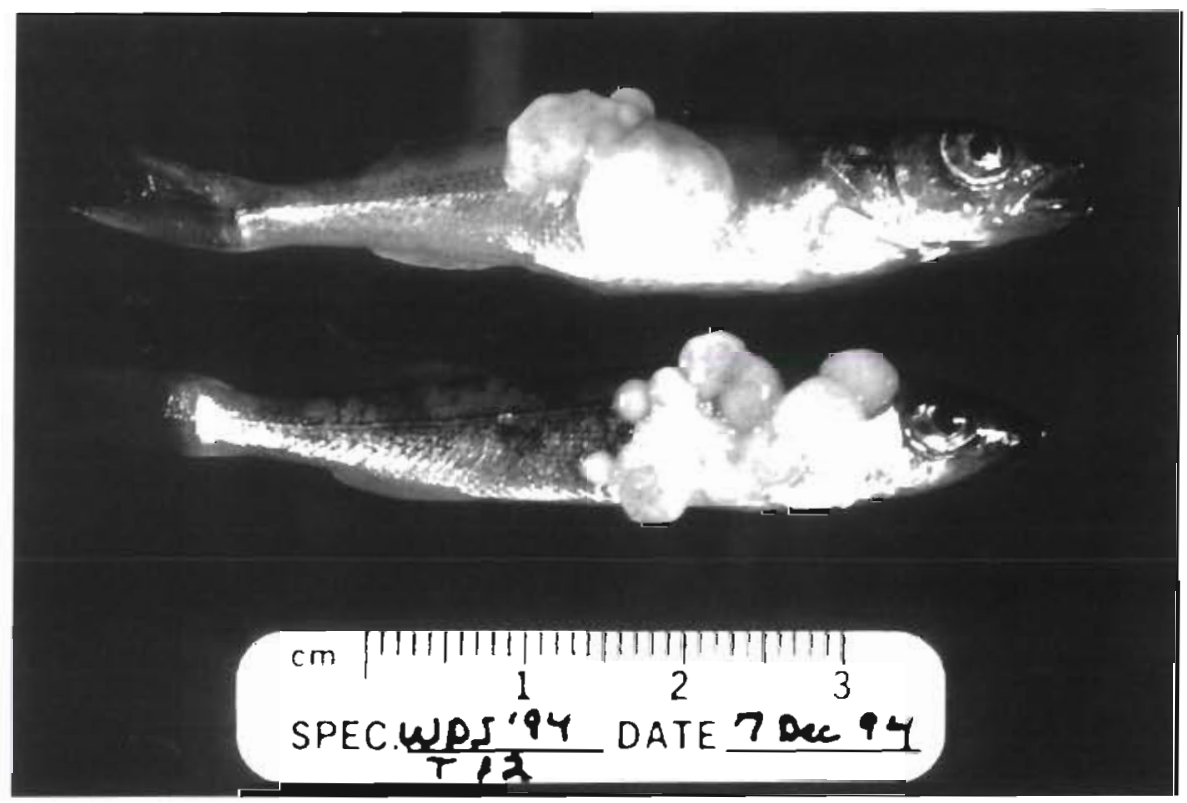

Fig. 1. Stizostedion vitreum. Youngof-the-year walleye with multiple, coalescing dermal sarcoma lesions 


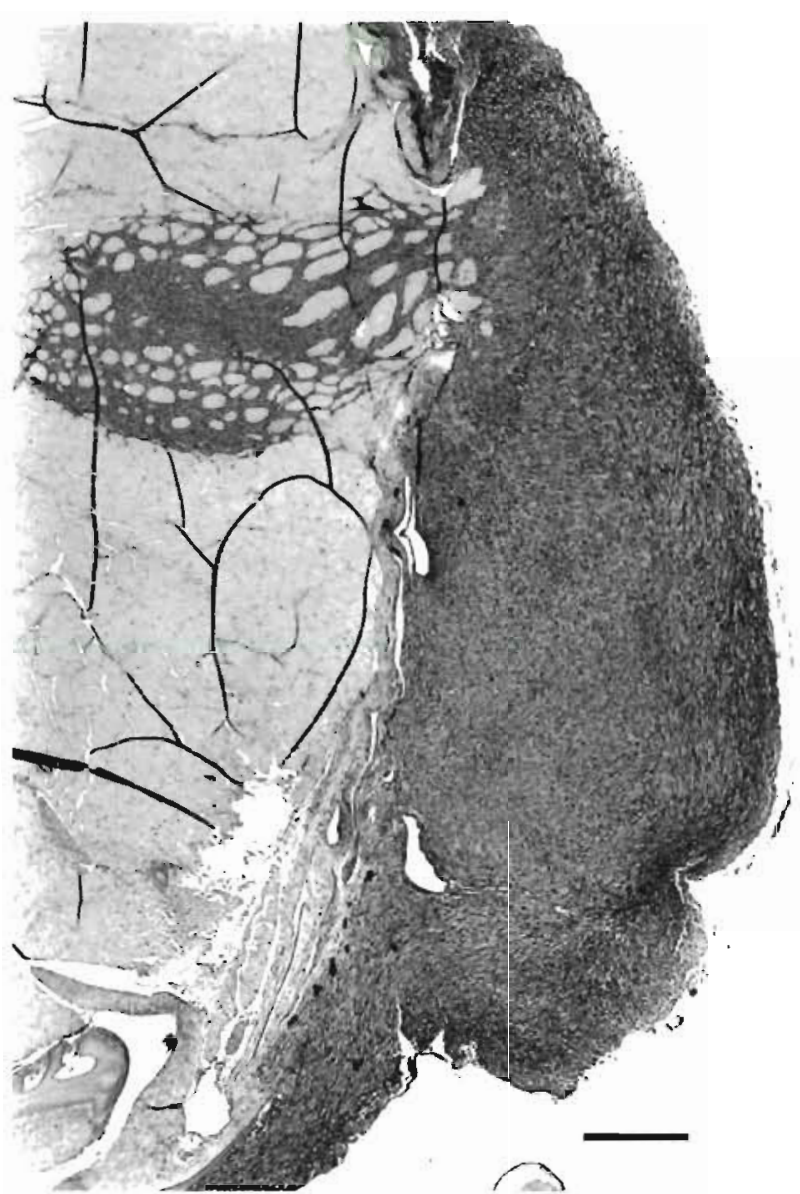

Fig. 3. Higher magnification of Fig. 2. H\&E. Scale bar $=286 \mu \mathrm{m}$

scale and underlying dermal bone have been invaded, including the skull on several specimens (Fig. 5). Several neoplasms of the head region appear to have compressed the brain (Fig. 6). Many of the neoplasms have grown to such huge dimensions that they have apparently outgrown their blood supply and have become necrotic. Despite the aggressive nature of the neoplasms in this trial, there is a low mitotic index of 1 to 2 per high-power field.

Multiple sections from several different fish have shown large numbers of multinucleated giant cells (Fig. 7). Additionally there is evidence of osteoid formation, with neoplastic cells forming columns of cuboidal cells surrounding a pale matrix resembling osteoblasts around an osteoid seam (Fig. 8). In addition to bone formation, there are foci which show death and destruction of bone and bone resorption, primarily vertebra (Fig. 9). In some locations, there is metaplasia of bone in the soft tissues of the neoplasm.

In other areas of the neoplasm, a collagenous stroma is being laid down by the neoplastic cells as background matrix, suggesting a fibroblastic origin. The neoplastic cells in these areas are fusiform with large, pale, elongated hyperchromatic nuclei. The nucleoli are often multiple and can be prominent. The fibroblast-like cells often form whorls and interwoven bundles. There are large bizarre syncitial cells present in several sections.

Discussion. As stated above, previous skin neoplasms of laboratory-transmitted WDS have been strictly superficial. This is the first time during a transmission study that there has been any evidence of local invasion into the surrounding musculature, and as such, these neoplasms were far more aggressive than those previously reported. In fact, on several sections, there was replacement of normal muscle by neoplastic cells.

There have been 5 reports of naturally occurring invasive sarcomas in walleye that have been catalogued by the Registry of Tumors in Lower Animals (RTLA 612, RTLA 749, RTLA 3396, RTLA 5922 and RTLA 5923; John Harshbarger pers. comm.). Upon review of these tissues, only one appears to have the same histopathologic presentation as those induced by the transmission study. Additionally, which is of interest, this neoplasm also showed signs of ossification and

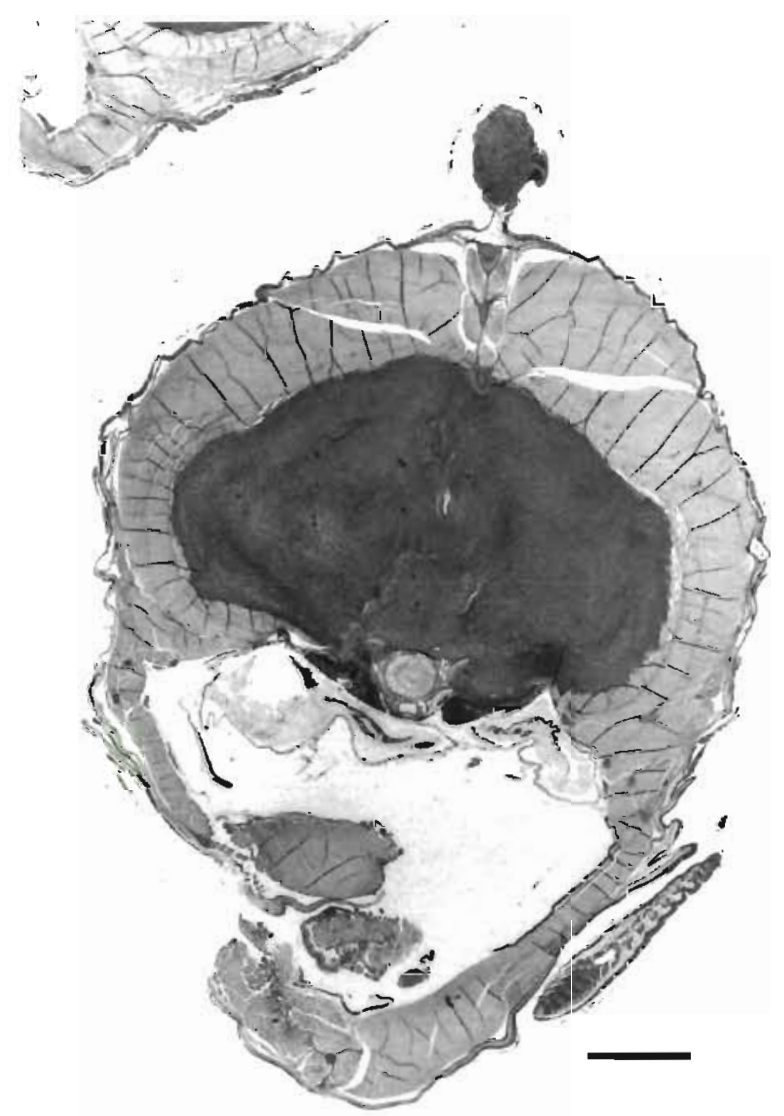

Fig. 4. Transverse section of the mid-region showing effacement and replacement of normal muscle by neoplastic cells. Note dermal sarcoma in dorsal fin. H\&E. Scale bar $=1.0 \mathrm{~mm}$ 


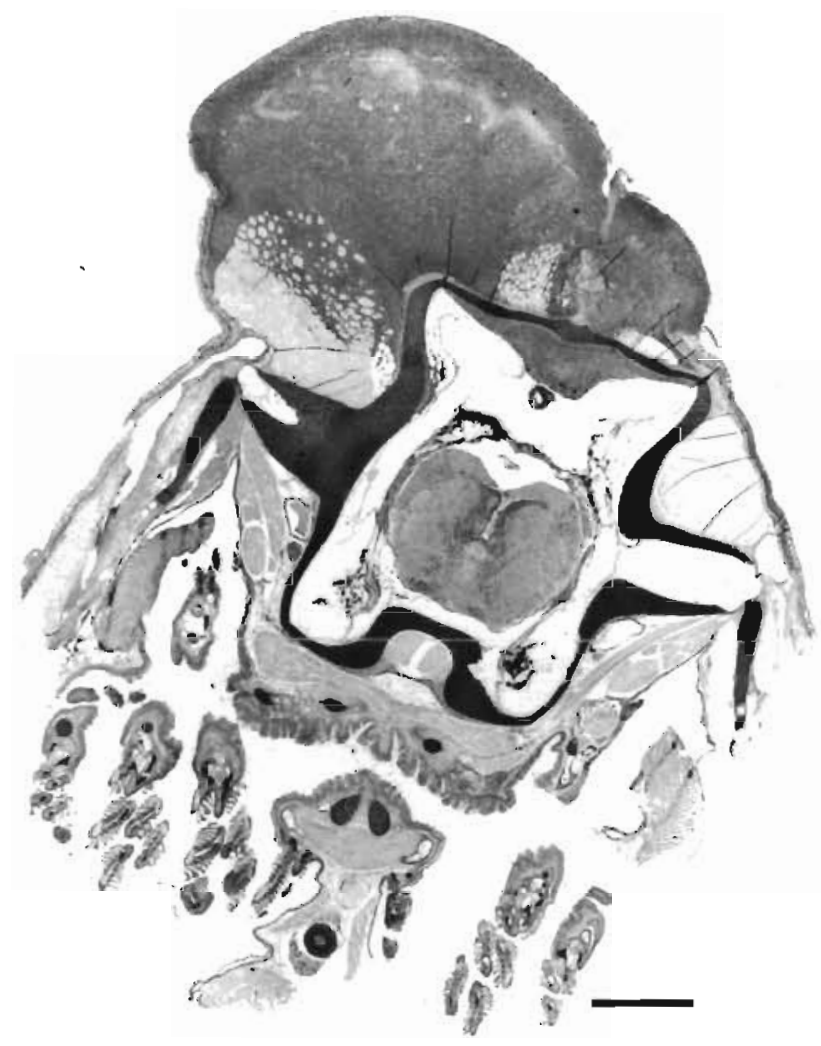

Fig. 5. Transverse section of skull showing large neoplastic mass which has infiltrated the cranium. H\&E. Scale bar = $0.83 \mathrm{~mm}$

bone formation within the tumor mass like those in the transmission study. The other 4 cases reviewed are examples of fibrosarcomas, but we are not convinced, based on the histopathological presentation of these

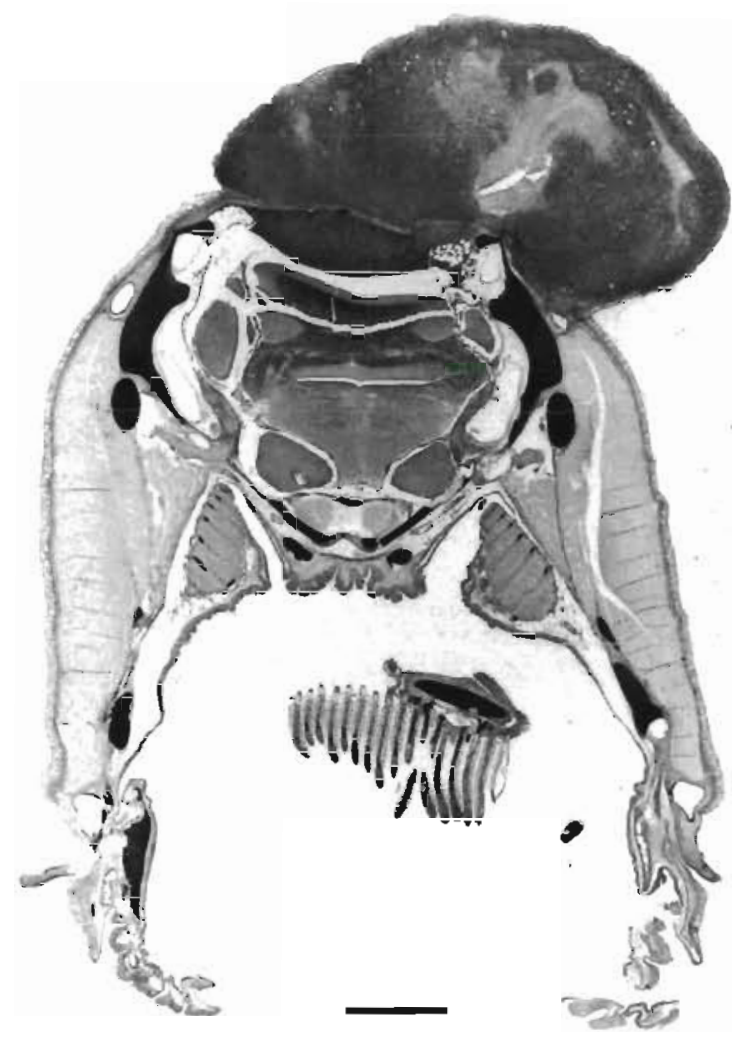

Fig. 6. Transverse section of skull showing necrotic neoplastic mass which has invaded the cranium and is compressing the brain. H\&E. Scale bar $=1.1 \mathrm{~mm}$

masses, that they are the retrovirally induced neoplasms characterized by the term 'walleye dermal sarcoma'. However, without the original tissues available to do further testing for the virus, this is just an opinion.

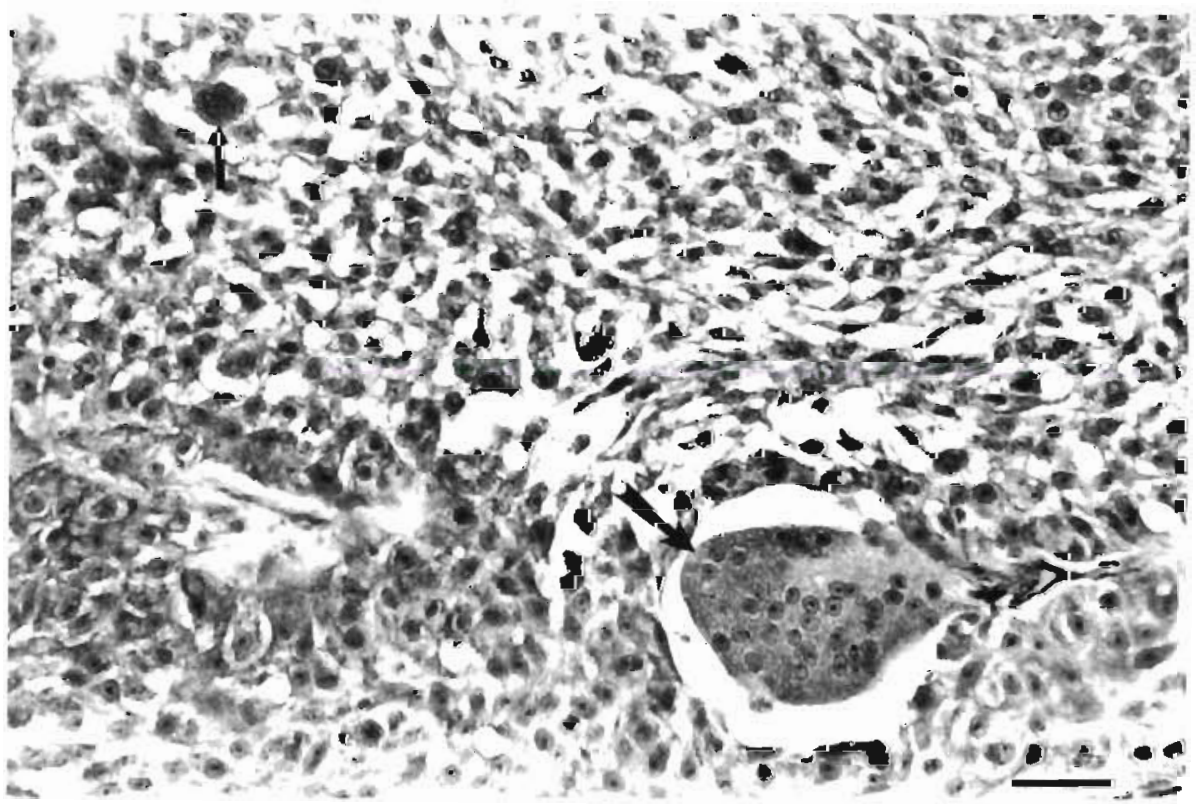

Fig. 7. Neoplasm showing multinucleated giant cells. Note variation in number of nuclei (small and large arrows\}. H\&E. Scale $\mathrm{bar}=28.6 \mu \mathrm{m}$ 
Fig. 8. Neoplasm showing osteoid formation. Note osteoblast-like cells (large arrow) surrounding osteoid matrix (small arrow). H\&E. Scale bar $=28.6 \mu \mathrm{m}$

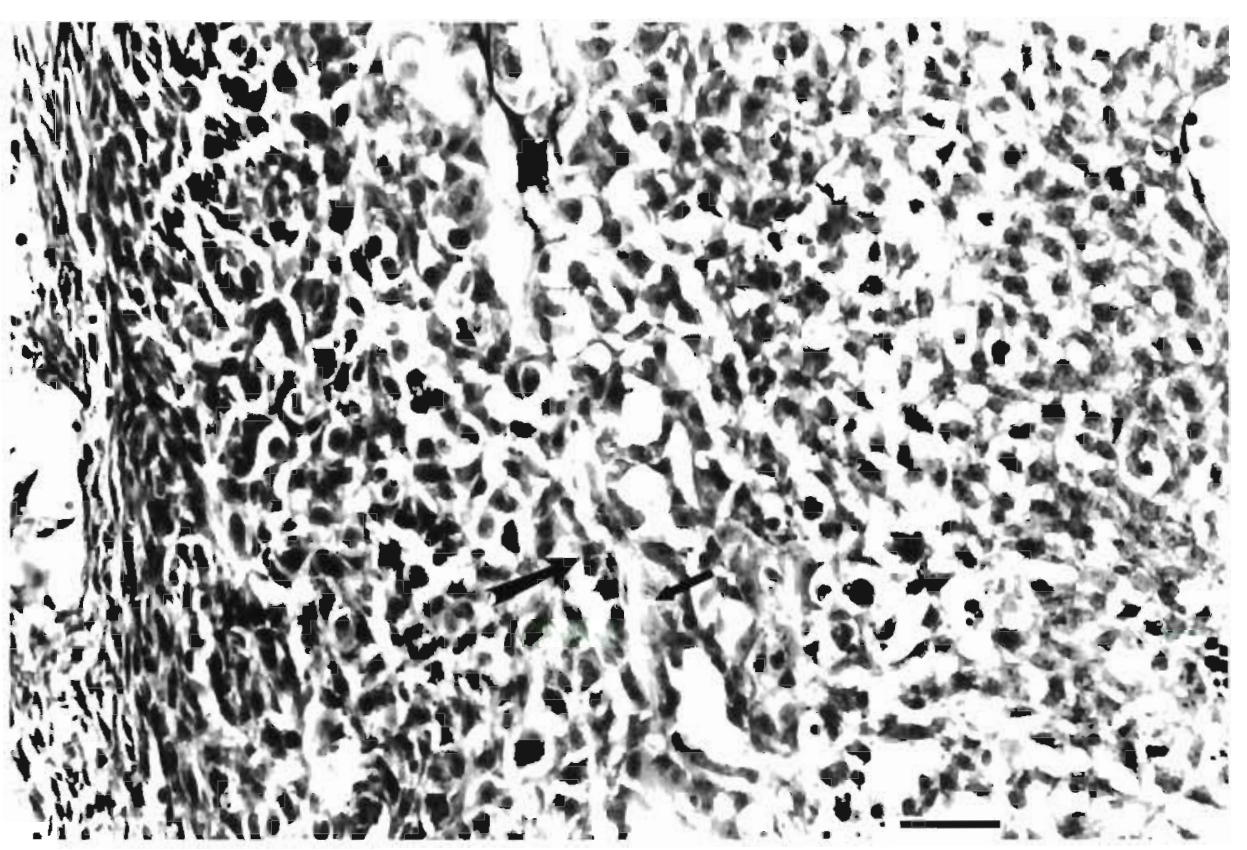

This neoplasm can best be descrubed as a pleomorphic sarcoma showing osteogenic differentiation. The presence of osteoblast-like cells forming and surrounding bone spicules is suggestrve of the neoplasm differentiating toward an osteosarcoma. The cell of origin of these neoplasms remains a mystery. Most lıkely it is a mesenchymal cell of dermal origin. As such it could be from any of the mesenchymal cells normally found in the dermis, such as dermal fubroblast, nerve or vessel.

These fish were injected at an earler age than those in previous transmission studies, $9 \mathrm{wk}$ versus $12 \mathrm{wk}$.
The invasive nature of the neoplasm may be due to an immature immune system whereby natural killer cell activity is low and thus the fish camnot mount an immune response to the neoplasm. In $\mathrm{t} 1 \mathrm{sh}$, natural killer cells are called nonspecific cytotoxic cells (NCC) and are the piscine equivalent of mammalian natural killer cells. It has been shown experimentally with trout NCC that these cells are able to inflict cytotoxicity on neoplastic cells both through apoptosis and necrosis (Greenlee et al. 1991).

Other factors which may have contributed to the neoplasm's invasiveness in these young walleyes is the
Fig. 9. Neoplastic mass invading and destroying vertebra (arrow) $\mathrm{H} \& \mathrm{E}$. Scale bar $=115 \mu \mathrm{m}$

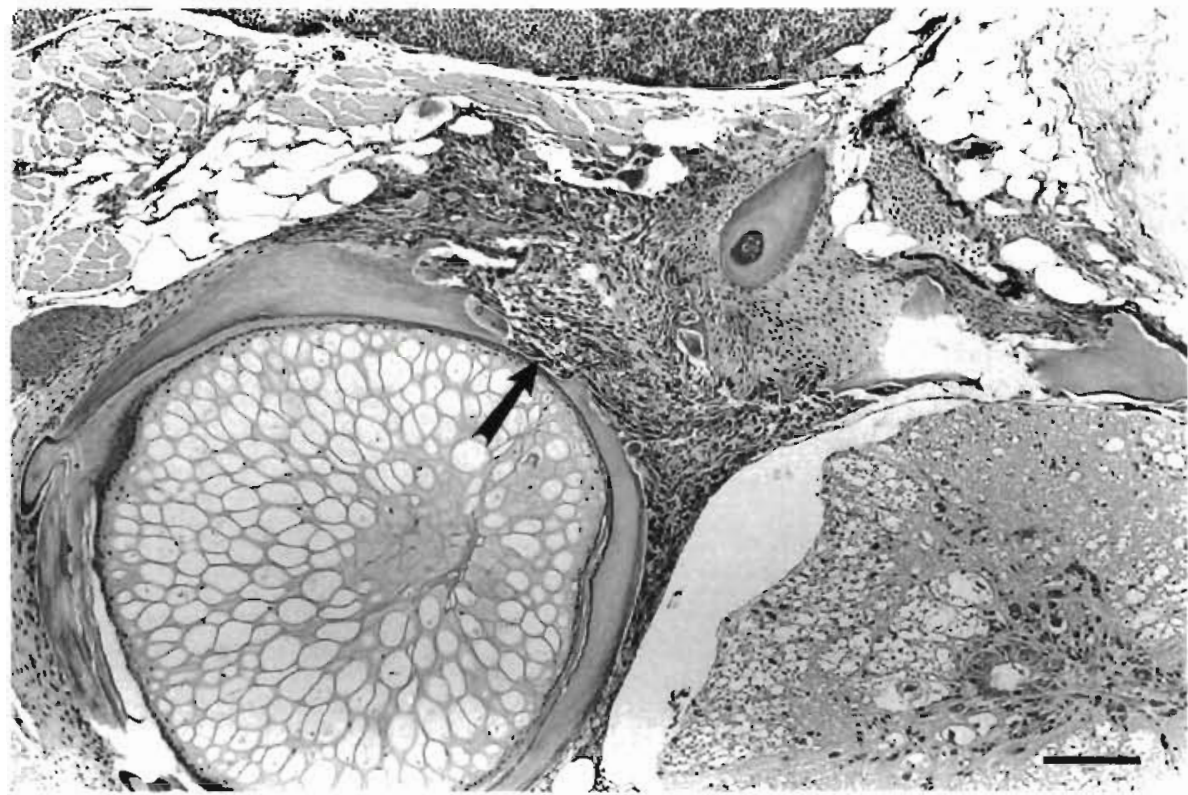


way the fish were housed and the aggressive nature of this species. Each aquarium held 15 young walleyes originally. The fish were fed fathead minnows. As walleyes dre piscivorous, they are highly competitive for the live bait. At times there were instances of cannibalism. In tilapia it has been shown that fish that are stressed have a decreased NCC activity. Social aggressiveness affects leukocyte functioning. Dominant fish have increased NCC activity, while fish that are subordinates or indeterminants have decreased activity due to social stress (Ghoneum et al. 1988).

Finally, diet may have a significant role in the functioning of the walleye NCC. These fish were fed fathead minnows ad libitum. In trout a link between NCC activity and a deficiency in essential fatty acids and zinc was reported (Kiron et al. 1993).

Acknowledgement. This work was supported in part by Public Health Service grant CA-53623A from the National Cancer Institute and by grant 93-03355 through the National Research Initiative Competitive Grants Program of the United States Department of Agriculture. We thank R. Colesante and P. Emerson of the New York State Department of Environmental Conservation for providing the walleyes used in this study. Additionally we thank Dr John Harshbarger from the Registry of Tumors in Lower Animals, George Washington University, Washington, D.C., for the loan of tissues from the registry for evaluation and comparison. Further, our sincere thanks to John Hnath, Michigan Department of Natural Resources, for in-depth case information for 2 of these registry cases. We also thank Alexis Wenski-Roberts for photomicroscopy support.

\section{LITERATURE CITED}

Bowser PR, Martineau D. Wooster GA (1990) Effects of water temperature on experimental transmission of dermal sarcoma in fingerling walleyes (Stizostedion vitreum) $\mathrm{J}$ aquat Anim Health 2:157-161

Bowser PR, Wolfe MJ, Forney JL, Wooster GA (1988) Seasonal prevalence of skin tumors from walleye (Stizostedion vitreum) from Oneida Lake, New York. J Wildl Dis 24: $292-298$

Responsible Subject Editor: F. M. Fletrick, College Park, Maryland, USA
Bowser PR, Wooster GA (1991) Regression of dermal sarcoma in adult walleyes. $J$ aquat Anim Health 3:147-150

Bowser PR, Wooster GA (1994) Ether sensitivity of the walleye dermal sarcoma virus. J aquat Anim Health 6:178-179

Ghoneum M, Faisal M, Peters G, Ahmed II, Cooper EL (1988) Suppression of natural cytotoxic cell activity by social aggressiveness in tilapia. Dev comp Immunol 12: $595-602$

Greenlee AR, Brown RA, Ristow SS (1991) Nonspecific cytotoxic cells of rainbow trout (Oncorhynchus mykiss) kill YAC-1 targets by both necrotic and apoptotic mechanisms. Dev comp Immunol 15:153-164

Kiron V, Gunji A, Okamoto N, Satoh S, Ikeda Y, Watanabe T (1993) Dietary nutrient dependent variations on natural killer activity of the leukocytes of rainbow trout. Fish Pathol 28:71-76

Martineau D, Bowser PR, Renshaw RR, Casey JW (1992) Molecular characterization of a unique retrovirus associated with a fish tumor. J Virol 66:596-599

Nidrlinedu D, Buwsel FR, Wuusier GA, Amstioñg LD (1930ā) Experimental transmission of a dermal sarcoma in fingerling walleyes (Stizostedion vitreum). Vet Pathol 27: $230-234$

Martineau D, Bowser PR, Wooster G, Forney JL (1990b) Histologic and ultrastructural studies of dermal sarcoma of walleye (Pisces: Stizostedion vitreum). Vet Pathol 27: $340-346$

Martineau D, Renshaw R, Bowser PR, Casey JW (1991b) Initial characterization of a retrovirus found in walleyes (Stizostedion vitreum). Second International Symposium of Virus of Lower Vertebrates Oregon State University Printing Department, Corvallis, p 157-163

Martineau D, Renshaw R, Williams JR, Casey JW, Bowser PR (1991a) A large unintegrated retrovirus DNA species present in a dermal tumor of walleye Stizostedion vitreum. Dis aquat Org 10:153-158

Walker R (1947) Lymphocystis disease and neoplasia in fish. Anat Rec 99:559-560

Walker R (1957) Warty walleyes. NY State Conserv 12:28-29

Walker R (1958) Lymphocystis warts and skin tumors of walleyed pike. Rensselaer Rev grad Stud 14:1-5

Walker R (1961) Fine structure of a virus tumor of fish. Am Zool 1:395-396

Walker R (1969) Virus associated with epidermal hyperplasia in fish. Natl Cancer Inst Monogr 31:195-207

Yamamoto T, Kelly RK, Nielson O (1985) Morphological differentiation of virus associated skin tumors of walleye (Stizostedion vitreum). Fish Pathol 20:361-372

Manuscript first received: February 17, 1995

Revised version accepted: August 30, 1995 